\title{
CODE MIXING ANALYSIS FOUND IN APLAUS MAGAZINE
}

\author{
Syahrul Efendi Lubis \\ Sekolah Tinggi Olahraga dan Kesehatan Bina Guna, Medan, Indonesia \\ syahrulfendi19@gmail.com
}

Submitted : 3/06/2021

Accepted : :3/06/2021

Publication : 4/06/2021

\begin{abstract}
This study deals with code-mixing in Aplaus magazine. The objective of the study is to analyze the components of language used in code-mixing namely word and phrase, then to find out the components of language which occurs dominantly in code-mixing in Aplaus magazine. This study is limited on the use of code-mixing only in English and Indonesian language in articles of Aplaus magazine and it taken randomly as the sample. The study was conducted by using descriptive quantitative design. The technique for collecting the data was a documentary technique. The data were analyzed based on the components of language which consists of word and phrase. Having analyzed the data, it is found that the components of language dominantly used is in word. Noun consists of 56 in the class of word, 5 for verbs, 4 for Adverbs, 2 for Adjectives, and 1 for interjection, while if it is seen from the class of word in phrase; 16 for noun phrases, 13 for adjective phrases, 2 for adverb phrases and the last 1 for prepositional phrase.
\end{abstract}

Keywords-- Code Mixing, Word, Phrase, Aplaus Magazine.

\section{Introduction}

Language takes an important role in humans' lives to interact and communicate because humans are social creatures that need others in order to fulfill their needs and help them to solve their problem. Language and human cannot be separated. If humans do not have language, there will be no communication between them. Through language, people are able to express their ideas, needs, experiences, thoughts, hopes, knowledges, feelings, and so on. Language can also be a person identity. When person uses correct language appropriately, it shows that person has good identity. Language entwined with human existence, it is part of the definition of social group (Bloomfield, 2014: 6). It can be meant that language and societies are influenced each other. The study between language and society called sociolinguistics. Sociolinguistics studies the relationship between language and society, speak differently in different social context, concerned with identifying the social functions of language and the way it is used to convey social meaning, examining the way people use language in different social contexts provides a wealth of information about the way language works, as well as about the social relationship in a community (Holmes, 1992: 1). According to Sumarsono and Partana (2004: 2) sociolinguistics is the study about language related to the condition of the society (learned by sociology), Pride and Holmes says that the study of language as part of culture and society

Furthermore, Wardaugh (1986: 103) states that code mixing is the use of two languages together by the conversant to the extent that they change from one language to the other in the course of a single utterance. Code mixing has become a worldwide phenomenon, which is very interesting to study and analyze. It is also deals with language change. In a language, changing takes place overtime. All living languages have changed and continue to change. In the other sides, code mixing caused by every people in a society has certain character in every situation where every character has certain norms (Bell in Giyoto, 2013: 65). Code Mixing usually happens because of special purposes such as for an identity and solidarity (Olivera in Giyoto, 2013: 65). The changing to another within the same utterances or the same oral written texts, it is a common phenomenon in societies in which two or more languages are used (Woon Yen 
Hoo, 2007:34). Code mixing is the most important features and well-studied speech processes in multilingual communities (Shorgen, 2002: 22).

Aplaus magazine is one example of indirect communication. It is weekly magazine that is published in Medan. Many code mixing utterances can be found in this magazine. It is written in Indonesian as the original language. This magazine uses simple language that can be easily understood by readers and is able to attract the readers expecially young readers to read the magazine. The writer chooses Aplaus Magazine as the subject of analysis because it has a lot of code-mixings in its articles. Furthermore, this article is simple, there is no politics issues here, there are so many appetite enhancer. In this magazines finds so many pictures also and the article talks about food which makes appetite enhancer of people raised. In this magazines, it finds some of motivation to other people, in order that they can save their money and can go tour to some of areas which is mentioned in this article. Besides, this magazines talks about entertainment and culinary, here, it will be stated some of events in Medan city specially. The most important why the writer takes the Aplaus's magazine is as an object of the research is Aplaus received a MURI award as the biggest free lifestyle tabloid in Indonesia by having 60.000 exemplar distributions in 2006. Years later, Aplaus The Lifestyle in the $100^{\text {th }}$ edition, changed its identity and aimed more specific market that targetted youngsters of 18-24 years old.

\section{Literature Review}

People use language in form of speaking, listening, writing, or reading. Language implies attention to the way language is played out in societies in its full range of functions (Bloomfield, 2014: 6). Because of that, people action varieties are related to language becomes the study about sociology of language, in many communities, different ethnic groups speak different language (Chambers, 1980: 7). From the explanation, the terminology of sociology of language since 1960 becomes new terminology. It is sociolinguistics (Pateda, 1987:2). Sociolinguistics is inter-discipliner knowledge. It is formed by sociology and linguistics. In sociolinguistics, the word socio is the main aspect and the general characteristic of the study. Whereas, linguistics has social characteristics because of language has social characteristics also, those are language and its structure only can develop in a certain society. In this case the social aspect has special characteristic, for example specific social characteristic and sound of language related to phoneme, morpheme, word, compound word, and sentence (Suhardi and et. al., 1995: 2).

Bram and Dickey (2002: 9) say that this sociolinguistics study focuses on how language functioned in a society, they also say that sociolinguistics explain human's ability in using language rules accurately in situation which has many variations. In the same definition, Nababan (1991: 2) says that sociolinguistics is a study related to language user as the member of society which studies and discusses about the aspects of language in a society, especially language variations related to social factors. Besides, sociolinguistics also related to an individual because of the element which usually emerges is involved to individual as the causing of individual function as social creature. This case is an linguistics opportunity which has social characteristic to involve to the society effect to language and the language effect to the function and the development of the society as the result of on both sides from the social elements in different aspects (Suhardi and et. al., 1995: 2) and (Coulmas, 1998:87) defines that sociolinguistics is the relationship of speech to social status, the correlation between language use and social structure.

\section{Scope of the Sociolinguistics}

Sociolinguistics interested in explaining why people speak differently in different social context. Sociolinguists are classified into two types. Those are micro sociolinguistics and macro sociolinguistics written bellow:

\section{Micro Sociolinguistics}


Micro sociolinguistics is the study about the language relation structure and social in the levels of face to face interaction (Giyoto, 2013: 43). Sociolinguistics is the study with the components of face to face interaction which related or influenced by the formal language structure and element outside language. Those elements related to personal, situation, the function of interaction, topic, message, and channel. It is related to small group (Pateda, 1987: 5). Giyoto (2013: 43) says that micro sociolinguistics related to the effort to relate the characteristics of language or the variation of language to the characteristics of communication or the situation of communication (Giyoto, 2013: 43). And how social structure influences the way people talk and how language varieties and patterns of use correlate with social attributes (Coulmas, 1998: 5). Besides, Fishman (1974: 242) states that micro sociolinguistics concerns on the study the in specific communities with the scope of discussion such as the behavior towards; language, register, speech act, and speech style. Micro sociolinguistics analyses, in which the emphasis is on the individual in small informal intra-group interactions, it includes to speech act, register not dialect (Tarjana, 2009; 2). If the discussion is about little thing, even narrow it's called micro sociolinguistics Sumarsono and Partana (2004: 14).

\section{The Macro of Sociolinguistics.}

Fishman (1974: 242) says that macro sociolinguistics is the study of sociolinguistics on language history and development in the scope of society in general. To support the definition of macro sociolinguistics, it needs to know about the differences between language and sociology. According to Sumarsono and Partana (2004: 5) describe that sociology explains about social structure, social organization, the relationship between societies and societies actions. Language is a necessary of every human group (Pateda, 1987: 2). From the explanation above it can be meant that language and society cannot be separated. If the discussion is about large scale, it is called macro sociolinguistics (Sumarsono and Partana, 2014: 14). Other linguist says that macro sociolinguistics is a kind of sociolinguistics analyses in which the locus of investigation is interaction at the large inter-group level: to the extent of studying nations and states in contact, linguistics features fall together under dialect, most linguistics variables will be found under dialect in broad sense (Tarjana (2009: 2). And it also said by Pateda (1987: 5) which macro sociolinguistic is related to language attitude and social structure. And also what societies do with their language (Coulmas, 1998: 5).

The definition of micro sociolinguistics and macro sociolinguistics above, which is explained by Fishman (1974: 242) the researcher emphasizes that micro sociolinguistics can be inferred that it deals with the use of language in certain society, it means that the analysis here included to micro sociolinguistics, because code mixing occurs within certain group of society in mass media, like magazine.

\section{Definition of Code Switching}

Bilingual speakers made choices between different language, they use one language on certain purposes and another language on others (Bloomfield, 2014: 165). Code Switching is one switches from one code to other while speaking, the situation dictates the use of language (Tarjana, 2009: 7). And it is a language switching because of situation changing (Chaer, 2014: 107) from formal situation to informal situation (Nababan, 1991: 31). Different from Olivera (2010: 107) who says that code switching not only happen between languages, but also happened by the variations and styles in language. Wardaugh (1998: 64) states that code switching as a changing from one code to other or mix a code in one brief utterance and from new utterance. And also used by who occupied high social status in the community (Bloomfield, 2014: 165). Other says that code switching happens caused by language contact and dependence each other (Padmadewi, 2014: 64).

Other linguist says that code switching is the use of language variation to do adaptation with other situation, or because of other participants (Suandi, 2014: 133). Code switching also is a switching from one dialect of language to other dialect (Pateda, 1987:71). Then it can be meant that code switching refers to the use of more than one language situation or more variation from one language in conversation (Suandi, 2014: 113). According to the definition 
above, it can be meant that code switching is a changing of codes caused by language contact and dependence each other. Besides, code switching also is the variations of code which switches one language to other to make addressee from different background understand about the conversation. The discussion of code switching here is presented as a complementary theory and will not be discussed further in the next chapter since this research does not include switching in its analysis.

\section{Research Method}

This research will be conducted by using descriptive qualitative research design. Michael (1987:42) saids that descriptive method provides a systematic, factual, and accurate description of a situation of area. Descriptive means describe, make a note, and analyze the conditions that occur. According to Djajasudarma (1993:10), there are two types of approach in a research; they are quantitative approach and qualitative approach. The writer applies qualitative approach because the data consist of the words, not the numbers. This research is called a qualitative one because the collected data are in the forms of sentences.

\section{Results and Discussion}

In this chapter, the writer presents the result of the research. This chapter discusses the phenomenon of code mixing that happens in printed media especially in magazine. Writer will analyze the code mixing in Aplaus magazine of April 2017 edition. The type of IndonesianEnglish code mixing according to Fasold can be classified into word and phrase. The forms of word cover the part of speech such as nouns, pronouns, verbs, adjectives, adverbs, conjunctions, prepositions and interjections. The phrase can be classified as noun phrases, verb phrases, adjective phrases, prepositional phrases and adverb phrases.

Further, writer analyses data which is only belongs to Indonesian-English code mixing. Before analyzing the data, it is necessary to reaffirm that not all the data will be analyzed. The data which will be taken into the analysis are those used by the journalists of Aplaus magazine. The data presented below are arranged according to types of their classification. In the analysis, writer finds some insertions of word and phrase. In the class of word, writer finds the some classes such nouns, adjectives, adverbs, and interjections. On the other hand the class of phrase that writer finds in Aplaus magazine such noun phrases, adjective phrases, adverb phrases and prepositional phrases. Mostly in the analysis that conducts by the writer, code mixing that is used by the magazine writers are the class of noun and noun phrase. In the other side, the factors that are found are internal and external factor covers low frequency of words, pernicious homonymy, synonym, social status, oversight, and the development of knowledge and new culture. In the analysis, writer finds low frequency of words as the most influence of the magazine writers to use code mixing. However, the development of knowledge and new culture is not found in this magazine.

\section{The Types of Code Mixing}

According to Suwito (1985:48), he explains code mixing covers the mix of two languages into two types. The code that is mixed is just the level of word and phrase. Mostly, in the analysis of research, writer finds noun and noun phrases as the majority in this analysis.

\section{Words}

Mostly, the form of code mixing that used in Aplaus magazine is the insertion of words. The magazine writers change Indonesian language words into other words in foreign language to find the synonym of the word that is not available in Indonesian language. Writer finds the class of nouns, verbs, adjectives, adverbs, and interjections as the representation of words insertion in Aplaus magazine.

\section{Noun}

In this research, writer finds found some of the English words as noun inserted in this magazine. Mostly, the word that writer finds in this magazine is nouns. A noun is a word that 
can be the name of persons, things, animals, places, and the concept of an abstracts. It is one of eight parts of speech which function also as subject and object in a sentence. The following are the examples of noun in a sentence that writer finds found in analyzing the data:

\section{Common Noun} (Page 26).

Sepatu, tas, belt, dompet atau barang apa pun yang terbuat dari kulit pasti lebih mahal.

The word 'belt' belongs to common nouns. Common nouns are words used to name general item rather than specific ones. They are general names for something. They are not capitalized unless begin a sentence or as the part of a title.

\section{Concrete Noun}

Sonar merupakan perwujudan visi festival music electronic modern yang sarat dengan kreatifitas dan teknologi (Page 08)

The words 'electronic' include concrete noun. Concrete noun is a noun that can be experienced according to sense. Sometimes concrete noun denotes an real object and activity. Tokyo tidak berhentinya berteriak ganbatte dari kilometer satu sampai garis finish (Page 07).

The words 'finish' include concrete noun. Concrete noun is a noun that can be experienced according to sense. Sometimes concrete noun denotes an real object and activity. Penganugerahan terhadap 9 bidang yang berbeda salah satunya fashion (Page 08).

The words 'fashion' include concrete noun. Concrete noun is a noun that can be experienced according to sense. Sometimes concrete noun denotes an real object and activity. Penganugerahan terhadap 9 bidang yang berbeda salah satunya food (Page 08).

The words 'food' include concrete noun. Concrete noun is a noun that can be experienced according to sense. Sometimes concrete noun denotes an real object and activity. Penganugerahan terhadap 9 bidang yang berbeda salah satunya health (Page 08).

The words 'health' include concrete noun. Concrete noun is a noun that can be experienced according to sense. Sometimes concrete noun denotes an real object and activity. Penganugerahan terhadap 9 bidang yang berbeda salah satunya youtube channel (Page 08).

The words 'youtube channel' include concrete noun. Concrete noun is a noun that can be experienced according to sense. Sometimes concrete noun denotes an real object and activity. Penganugerahan terhadap 9 bidang yang berbeda salah satunya youtube personality (Page 08).

The words 'youtube personality' include concrete noun. Concrete noun is a noun that can be experienced according to sense. Sometimes concrete noun denotes an real object and activity.

Masih ada kesempatan kedua untuk menyimak penampilan band asal Inggris ini di negeri... (Page 08)

The words 'band' include concrete noun. Concrete noun is a noun that can be experienced according to sense. Sometimes concrete noun denotes an real object and activity.

\section{Abstract Noun}

Penganugerahan terhadap 9 bidang yang berbeda salah satunya fitness (Page 08)

The words 'fitness' include abstract noun. Abstract noun is a noun that cannot be experienced according to sense. Sometimes abstract noun denotes an ideas, qualities, or state rather than concrete objects.

Pria kelahiran Palangkaraya ini menyukai dunia travelling sejak usia dini (Page 04)

The words 'travelling' include abstract noun. Abstract noun is a noun that cannot be experienced according to sense. Sometimes abstract noun denotes an ideas, qualities, or state rather than concrete objects.

Acara yang diadain Ophélie Renouard ini bertujuan ngumpulin dana untuk charity, seperti untuk Enfantsd'Asie humanitarian program anak, Mélita Bern-Schlanger Findsation dan Feed Findsation. (Page 17)

The words 'charity' and 'humanitarian' include abstract noun. Abstract noun is a noun that cannot be experienced according to sense. Sometimes abstract noun denotes an ideas, 
qualities, or state rather than concrete objects.

\section{Countable Noun}

Acara ini akan menganugerahkan influencer ternama di 9 bidang (Page 08)

Countable nouns are individual people, animals, places, things or ideas which can be counted. They have a singular and a plural form. Singular form can use the determiner "a" or "an". Plural forms are formed by adding "s" or "es" in the end of the noun or sometimes a specific noun has irregular plural form. The word 'influencer' in the sentence belongs to singular form. It formed by adding suffix"er" after the word 'influence'.

Tentu saja menjadi farmer! (Page 05)

Countable nouns are individual people, animals, places, things or ideas which can be counted. They have a singular and a plural form. Singular form can use the determiner "a" or "an". Plural forms are formed by adding "s" or "es" in the end of the noun or sometimes a specific noun has irregular plural form. The word 'farmer' in the sentence belongs to singular form. It formed by adding suffix"er" after the word 'farm'.

Ketika itu, saya mencoba kategori 50 kilometer pada event Samosir Lake Toba Ultra Marathon 2016 (Page 07)

Countable nouns are individual people, animals, places, things or ideas which can be counted. They have a singular and a plural form. Singular form can use the determiner "a" or "an". Plural forms are formed by adding "s" or "es" in the end of the noun or sometimes a specific noun has irregular plural form. The word 'event' in the sentence belongs to singular form.

Dulu supaya bisa deket, fans Cuma bisa ngarep ketemu idola di panggung konser. (Page 09)

Countable nouns are individual people, animals, places, things or ideas which can be counted. They have a singular and a plural form. Singular form can use the determiner "a" or "an". Plural forms are formed by adding "s" or "es" in the end of the noun or sometimes a specific noun has irregular plural form. The word 'fans' in the sentence belongs to plural form. It formed by adding "s" after the word 'fan'.

\section{Uncountable Noun}

Angkat dan keringkan kaki. Lalu oleskan coffee pada lengan kaki yang kasar dan kering. (Page 12)

Uncountable nouns are for the things that it cannot count with numbers. They may be the name for abstract ideas or qualities or too amorphous to be counted such as liquids, powders, gases, etc. Uncountable nouns usually do not have plural form. In the sentence the word 'coffee' belongs to uncountable noun. It cannot be counted by number but needs a counter to measure.

\section{Verb}

The verb is a word which has function to refer an act that the subject doing. It is one of eight parts of speech that can be divided into two based on its form regular and irregular verb. Based on the presence of object, it is classified into a transitive and intransitive verb.

\section{Transitive Verb}

Total hutangnya saat meninggal dunia adalah $\$ 500$ juta, ini termasuk $\$ 17$ juta buat beli Neverland, ditambah lagi $\$ 10$ juta buat biaya maintain per bulan (Page 16)

An action verb with a direct object is transitive verb while an acting verb with no direct object is intransitive. According to Oxford dictionary, the word 'maintain' includes into transitive verb. It means that the verb needs object to complete the idea.

\section{Intransitive Verb}

Saat chat, tekan dan tahan "Hold to Talk" sambil menyampaikan pesan suara (Page 10)

An intransitive verb has two characteristic. First, it is an action verb expressing a doable 
activity and the second one unlike transitive verb, it will not have direct object receiving the action. The word 'chat' belongs to intransitive verb which does not need object to complete the idea of the magazine writers.

\section{Adjective}

An adjective is a word that modifies noun or pronoun. It can be divided into some types and sometimes, it is formed by adding some affixes. It is also divided into single adjective, derived adjective, or sometimes it becomes a participle. Writer finds some adjectives as follows: Single Adjective

Dibalik suasana pekantoran SCBD yang super hectic, Kopitiam Tan hadir dengan konsep tradisional modern yang nyaman dan homey. (Page 15)

The word 'hectic' in the sentence above is single adjective. However, some words endings or suffixes are typical of adjective, they called derived adjectives. For instance, the sentence above is also contained derived adjective: 'homey'. It becomes an adjective by the forming of word 'home' then add by suffix $-\mathrm{y}$.

\section{Derived Adjective}

Detail dan desain yang timeless juga jadi andelan brand jam Patek Phillipe \& Co. (Page 29)

Derived adjective is a noun or verb that becomes an adjective by adding a suffix or suffixes at the end of the word. From the sentence, the adjective 'timeless' consists of the word 'time' as noun and -less as suffix. The combination of noun and suffix becomes an adjective.

\section{Participle}

Mereka juga excited dengerin sharing dari mbak Indri dan mbak Debora. (Page 21)

A rt participle is a word formed from verb and adjective that is used in a sentence to modify a noun, noun phrase, verb, or verb phrase, and it plays the role similar to an adjective or adverb. There are two kinds of participle, they are present and past. In the sentence above, there is a past participle represents the word 'excited'. It has function to modify noun that comes before it.

\section{Adverb}

Adverb is a word that modifies a verb, an adjective, or another adverb. It is one of eight parts of speech. It is classified into adverb of time, manner, place, frequency and attitude. In analyzing the data, writer finds adverb in a sentence as follows:

Unfortunately, banyak media nge-cap Tay as serial dater yang sering gonta-ganti cowok demi lagu! (Page 24)

The adverb in the sentence above is the word 'unfortunately'. 'Unfortunately' belongs to the adverb of attitude. It tells something about the speaker's opinion about the information expressed. Adverbs of attitude are often placed at the beginning of a sentence in order to give a kind of context in the rest of the sentence.

\section{Interjection}

An interjection is a short greeting that is used to express emotions. Interjection is followed by a comma or exclamation and sometimes it is followed by a question mark. Writer finds one interjection as follows:

Bagi kamu penyuka cake, ngga afdol rasanya kalau belum nyicipin Chocolate Lava Cake, fondant cake lezat dengan filling chocolate melted dipadukan dengan ice cream vanilla sehargaRp 15.000 aja hmm...yummy! (Page 35)

From the sentence above, writer finds interjection as the word 'yummy'. This expression sometimes is used by people to express happiness and satisfaction while eating food which has good taste.

\section{Phrase}


Phrase is a meaningful group having no subject and predicate. This group of words has such function as nouns, objects, adjectives or adverbs. These types of phrases are determined by the keyword. In analyzing the data, writer finds noun phrases, adjective phrases, adverb phrases and prepositional phrases.

\section{Noun Phrase}

Noun phrase is a group of words that its head is a noun. It is used when a single noun cannot be specific enough to refer a noun. It has function as a subject or object in a sentence. This sentence below is the example of noun phrase in the analyzing the data:

Mulai saat ini, saya akan stay committed untuk terus berlari (Page 07)

The phrase 'stay committed' is noun phrases. The phrase stay committed of a noun (committed) as its head and a modifier (stay).

Kota Medan punya 2 playground baru yang cocok disambangi anda bersama dengan keluarga (Page 04)

The phrase 'playground' is noun phrases. The phrase playground consists of a noun (ground) as its head and a modifier (play).

Bagi fotografer kawakan kota medan ini. Food photography menawarkan tantangan tersendiri (Page 04).

The phrase 'food photography' is noun phrases. The phrase food photography consists of a noun (photography) as its head and a modifier (food).

Karena kesan leather yang mewah dan mahal Stella McCartney, seorang desainer asal Inggris, bahkan mempromosikan biodegradable suede, atau fake suede yang digunakan dalam rancangannya untuk menghindari pemkaian leather tanpa mengurangi nilai estetis karyanya. (Page 27)

The phrase 'biodegradable suede' and 'fake suede' are noun phrases. The phrase biodegradable suede consists of a noun (suede) as its head and a modifier (biodegradable and fake).

\section{Adjective Phrase}

Adjective phrase is a group of words that describes a noun or pronoun in a sentence. An adjective phrase always has adjective acting as head. Adjective phrases can be accompanied by other words such as determiner and modifier. Writer finds the example of adjective phrase in sentence as follows:

Visual Artist

Bagi Enora Lalet, seorang visual artist asal Perancis (Page 04) (artist).

The phrase 'visual artist' consists of an adjective (visual) as a head and a modifier

\section{Ethical Hacker}

Intip 10 kampus yang menawarkan pendidikan non-konvensi.onal bagi anda, baik belajar di kampus burger, menjadi ethical hacker, (Page 05)

The phrase 'ethical hacker' consists of an adjective (ethical) as a head and a modifier (hacker).

Long lasting

Stabilnya harga logam mulia ini tentu nggak lepas dari sifatnya yang long lasting. (Page 13)

The phrase 'long lasting' consists of an adjective (long) as a head and a modifier (lasting).

Most important

Most important jangan lupa air minum yang banyak. (Page 25)

In the sentence above, the insertion of phrase is 'most important' that consists of 'most' as a modifier and 'important' as the head of adjective.

Super gloomy

Misalnya bilang ke sahabat, "Daripada pasang status super gloomy, mending cerita kenapa berantem sama pacar." (Page 23)

The phrase 'super gloomy' is an adjective phrase which consists of 'super' as a modifier and 'gloomy' as the head of adjective. 


\section{Adverbial Phrase}

An adverbial phrase is a group of words that acts together as an adverb, giving more information about a verb, adjective, or other adverb in a sentence. Adverb phrase is a group of words that consists of an adverb with a qualifier, or a group of words such as: propositional phrase that can be functioned as an adverb. From analyzing the data, writer finds an adverb phrase in sentence as follows:

Kabar terbaru dari dua perusahaan fast food raksasa asal Amerika Serikat yang melakukan merger (page 04).

From the sentence above, the bold mark is a an adver phrase that has function as adverb of manner. The function of adverb phrase in that sentence is to explain the kind of food.

Nama ini diambil dari YS Media dengan tujuan memberi sensasi yang lain on stage. (Page 14)

From the sentence above, the bold mark is a preposition phrase that has function as adverb of place. The function of adverb phrase in that sentence is to explain the place of the event.

\section{Prepositional Phrase}

The combination of preposition and its object which are able to be a noun, pronoun or gerund. A preposition that is used can be a single preposition or complex preposition. It is a word that indicate the relationship between various elements within a sentence.

Kalau low season, kita bisa pesan hotel on the spot. (Page 22)

The phrase 'on the spot' consists of preposition (on) and an object of preposition (the spot). The function of this preposition phrase is as adverbial of place, preposition or complex preposition. It is a word that indicate the relationship between various elements within a sentence.

\section{Factors Influencing the Use of Code Mixing in Aplaus Magazine}

In the study code mixing, it does not only study about the forms, but the factors influencing code mixing are also important to be explained. In the analysis, writer finds the factors that are often influence the use of code mixing in Aplaus magazine is internal factor as low frequency of word. Meanwhile, the factor of the development of knowledge and new culture does not find in the analysis. The factors influencing the use of code mixing in Aplaus magazine are as follows:

\section{Internal Factor}

Low frequency words

Backpacker

Apalagi kalo selama ini rencana kita ikutan kelas dansa, backpacker, atau les masak musti kepending karena mantan. (Page 63)

Low frequency of words is the using of borrowing words from other languages terms than Indonesian language terms which are rare to hear for completing the meaning. A person used code mixing because the words are often used, it is easier to remember than using it in own language. For that statement above, they are rather to choose 'backpacker' than the term in Indonesian language. It is easy to hear the term 'backpacker' when it is discussing about travelling to anyone than using in Indonesian language "traveling with limited budget" which has same meaning with 'backpacker'. So, the borrowing of other languages terms has a function to avoid the word that is rarely heard by the readers.

Bully

Nge-bully fisik atau mental. (Page 62)

Today the word 'bully' is common to hear among young people conversation. The word 'bully' is easier to hear than Indonesian word. In Indonesia bully means penindasan. Although in Indonesian language there is the word that has same meaning with 'bully', but today the word 'bully' is often to use.

Movie marathon

Movie marathon sendirian di bioskop. (Page 64) 
'Movie marathon' is the term to refer an activity for watching movie at least two or more movies in the same time. Sometimes, 'movie marathon' is watching a full series of a movie. So, it can sit along six hours or more in front of the monitor. Indonesian has no term to refer this activity. Indonesian people are often to use 'movie marathon' rather in Indonesian language.

Move on

Terjebak di masa lalu dan rasanya susah banget buat

move on, Waktunya get over it, bangun dan move on! (Page 66)

Actually the word 'move on' can use by people in many occasions. It is used to express something that should be left and move to the new one. However, in the sentence the context is discussing about move on someone in relationship. Lately, the word 'move on' is usually used by people to refer leave someone in the past (ex boyfriend or girlfriend) and having the relation with the new one. Indonesian language has same meaning with 'move on' as berjalan terus but it is not appropriate to use in the context of the sentence.

Pernicious homonym

Tapi kalau udah berubah jadi obsessive hate, sampai kita jadi stalking diatiap hari, seneng kalo dia dapet masalah, atau pengin nunjukin kalo kita lebih hebat dari dia, berarti ada yang harus kita perbaiki nih. (Page 67)

In case to avoid the ambiguity, they borrow other languages terms. It means that if the magazine writers use Indonesian language words, it could make a homonym problem. For that statement, the word 'stalking' in Indonesian language means menguntit, if they use it in that sentence, the readers will be confused with the meaning. In Indonesia, the word menguntit is usually has negative meaning because it is used to describe bad habit like walking behind person in every time. However, the word 'stalking' does not refer to bad habit for people because it is used in social media and people can do it every time when they need. The word 'stalking' is used to describe an activity to watch someone in social media. It has different meaning in Indonesian language in common.

\section{Synonym}

Drama queen

Jadi drama queen, ngegede-gedein semua hal supaya perhatian tertuju cuma

buat kita seorang.(Page 62)

The magazine writers use foreign languages to soften the meaning. They try to avoid the words or terms that make a rough meaning. The example of the using of synonym in that sentence is showed in phrase 'drama queen'. It is intentionally used by the speaker to address a person who frequently gives excessively performance or reaction. In Indonesian language, drama queen means orang lebay (overact). In Indonesia when a person called as orang lebay, he or she will be embarrassed so they try to soften the meaning by using the term drama 'queen 'rather than explaining the true meaning of the term.

Bragging

Bragging tentang pencapaian pribadi dan keahlian yang dimiliki. (Page 62)

In the sentence, the magazine writers are also use English word instead of Indonesian language to soften the meaning. 'Bragging' which means membual in Indonesian language, is too rude to use in written language mainly in a magazine. They try to make the sentence more acceptable for the readers that the majority are young people.

Attention seeker

Marisa bilang, ketika attention seeker ngerasa nggak dapat cukup atensi, perilaku mereka bisa saja terus meningkat, bahkan ada yang berpura-pura pingsan atau mencoba bunuh diri! (Page 63)

The sentence above is discussing about attention seeker's drama that very often happens in young people's life today. In Indonesia, it knows the term cari perhatian (caper) to refer the term 'attention seeker'. The term caper in Indonesia is used to refer a person who always looking for people's attention to get a compliment or sympathy. When a person is called as caper, they will reject because it is like mock his or her. 'Attention seeker' has same meaning with caper, but it is softer to hear. It is behaving in a way which is in pursuit of attention from 
others. The attention they receive gives them a good feeling and boosts their self-esteem and self-worth. So, the magazine writers use the term attention seeker than caper to make the meaning more acceptable for the readers.

\section{External Factor}

Social value

Winter

Banyak, pas syuting itu letak studionya di daerah

pegunungan, kebetulan juga pas winter. (Page 19).

The magazine writers use foreign languages to show someone social status or to attract the object they are talking about. In the magazine writer finds the word 'winter'. The winter season does not take place in Indonesia, the four seasons usually occur in foreign country. Indonesia has two seasons, dry and rainy season.

In Indonesia, the stereotypes as rich people are given to them who are going abroad. The magazine writers interviewed girl band from Indonesia who has been trained in Korea for winter season. It shows us this girl band is not like a common girl band from Indonesia because they have been trained in Korea.

International school

Kelas 4 SD aku dipindahin ke International School. (Page 14)

Lately, international school becomes one of the choices by the parents to send their children. It serves the best facilities to support learning activity. Since it is built by private, the cost to spend in International school is different from public school, the cost spent may more higher, therefore people distinguish international school for rich people due to the cost is very expensive. According to the sentence, aku refers to the daughter of Chairul Tanjung. He is one of the richest men in Indonesia. So, by mention the word 'International school' the readers will know that she is rich.

Oversight

Kate Middleton mutusin untuk mematenkan namanya buat merk clothing line. (Page 210)

Oversight is the using of other languages, it caused people have the limit of words to complete their sentence. When they talk about clothing business, they will mention the word 'clothing line', it is a company or store that produces clothes with their own brand. Indonesian language does not have the term to replace it. They use the word 'clothing line' to mention company or store that sell.

\section{Conclusion}

From the analysis and discussion above, writer concludes that code mixing is the use of two or more languages by transferring from one language into others and vice versa. Code mixing is the phenomenon that happens in opened speech community which is willing to accept the influence from outer. It occurs especially in bilingual or multilingual society. A speaker that is having specific social background tend to choose specific code mixing to show the social status or personal identity in his society and to show familiarly or solidarity. Aplaus journalists mix their language from Indonesian language into English to express their message. The causality that exists between the journalists and the readers is the relationship reciprocal between language form and language function. It means that the journalists have specific social background to mix two languages. In this magazine, writer discovers the use of IndonesianEnglish code mixing. From the analysis, the magazine writers use informal code mixing in their writing. It is used to make closer with the readers. This research found two types of code mixing used in Aplaus Magazine April 2017 Edition according to Fasold. Those are the insertion of word and phrase. From the research, writer finds 100 codes mixing in Aplaus Magazine April 2017 Edition which covers the insertion of words and phrases.

It consists of the mixing of words insertion as much as 100 insertions cover of noun 56, adjective 2, adverb 4, verb 5 and interjection 1. Phrases insertion as much as from 100 insertions cover of noun phrase 16, adjective phrase 13, adverb phrase 2 and prepositional phrase 1 . Code mixing in this magazine is mostly noun insertion as much as 56 and noun phrase 16. This research found some social factors for the use of code mixing in Aplaus Magazine April 2017 
Edition. According to Weinreich about the factors of code mixing, writer analyzes them that influence the use of code mixing in Aplaus magazine. The factors are internal and external. Internal factors include low frequency of words, pernicious homonym, and synonym. The external social are the development of knowledge and new culture, social status and oversight. In the analysis, writer finds low frequency word as the factor that mostly influences in Aplaus magazine. However, the external factor as the development of knowledge and new culture did not find in this magazine.

\section{References}

Bell, Bernard. 2013. Sociolinguistics. Spain: Oxford University Press.

Bram and Dickey. 2002. The Power of Society. Cambridge: Cambridge University Press.

Chaer, Abdul and Leonie Agustina. 2014. Sosiolinguistik Perkenalan Awal. Jakarta: PT. RinekaCipta.

Chambers, J.K. 1980. Dialectology. USA: Press Syndicate.

Coulmas. 1998. The Effect of Language. New York: Monarch Press.

Criper and Windowson. 2013. Language: An Introduction to the Study of Bilingualism. New York. USA: Harcourt, Brace, and Company

Djajasudarma, T Fatimah. 1993. Metode Linguistik Ancangan Metode Penelitiandan Kajian. Bandung: ERESCO.

Fishman, Joshua A. 1974. Sociolinguistics: A Brief Introduction. United State: Newbury House Publishers.

Giyoto, Suwito. 2013. Pengantar Awal Sosiolinguistik Teori dan Problema. Surakarta. Henary Offset Solo.

Hartanti. 2014. The Phenomenon of Code Mixing on the Novel Manusia Setengah Salmon Written by RadityaDika. Semarang. Diponegoro University. Thesis Unpublished.

Holmes, Janet. 1992. An Introduction to Sociolinguistics. London and New York: Longman.

Haugan, R.A. 2014. Sociolinguistics. London: Cambridge University Press.

Kliment. 2014. Rhetorical of Code Mixing, The Encyclopedia Americana. Volume II, Connecticut: Grolier in Corporated.

Miles and Huberman. 1994. Research Design. New York: Monarch Press.

Moleong, Lexy. J. 2008. Metodologi Penelitian Kualitatif. Bandung: PT. Remaja Rosdakarya.

Nababan, P.W.J. 1991. Sosiolinguistik Suatu Pengantar. Jakarta: PT. GramediaPustaka.

Padmadewi, Novita. 2014. Code Mixing Analysis of the Judges Comments. Yogyakarta: Media Press.

Pateda, Dallin. 1987. An Introduction to the Language. New York. USA: Harcourt, Brace, and Company.

Olivera . 2013. Bahasa dan Komunikasi. Semarang: Bumi Prasindo.

Richards, Hawkes. 1985. Introduction to Sociolinguistics. Cambridge: Cambridge University Press.

Shorgen. 2002. The Power of Language. New York: Random House.

Suandi, Fathur. 2014. Sosiolinguistik Suatu Pendekatan Pembelajaran Bahasa dalam Masyarakat Multikultural. Yogyakarta: GrahaIlmu

Suhadi. 1995. Metode dan Aneka Teknik Analisis Bahasa. Yogyakarta. Duta Wacana University.

Sumarsono dan Partana. 2004. Sosiolinguistik. Yogyakarta: SABDA

Susan. 2004. Definition of Bilingualism. New York: Ha rcourt Brance and World-in.

Suwito. 1985. Metode Linguistik Bagian Pertama ke Arah Memahami Metode Linguistics. Yogyakarta: UGM Jogja.

Tarjana. 2009. Code Mixing. Surabaya: Bumi Aksara.

Wardhaugh, Ronald. 1996. An Introduction to Sociolinguistics. New York: Basil Blackwell.

Weinrich, Ralp. 1982. The Sociolinguistics of Society. New York: Basil Blackwell.

Woo Yen Hoo. 2007. An article why do people use code mixing in the article? In Journal of Language and Social Psychology. September I 2007 28: 263-280. Memphis: Department of Psychology, Memphis State University. 